2010

\title{
Doing the Business: Judges, Academics, and Intellectuals
}

Allan C. Hutchinson

Osgoode Hall Law School of York University, ahutchinson@osgoode.yorku.ca

Follow this and additional works at: http://digitalcommons.osgoode.yorku.ca/scholarly_works

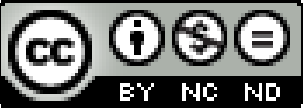

This work is licensed under a Creative Commons Attribution-Noncommercial-No Derivative Works 4.0 License.

\section{Recommended Citation}

Hutchinson, Allan C. "Doing the Business: Judges, Academics, and Intellectuals." University of Queensland Law Journal 29.1 (2010): 133-142.

This Article is brought to you for free and open access by the Faculty Scholarship at Osgoode Digital Commons. It has been accepted for inclusion in Articles \& Book Chapters by an authorized administrator of Osgoode Digital Commons. 


\title{
DOING THE BUSINESS: JUDGES, ACADEMICS, AND INTELLECTUALS
}

\author{
ALlAN C. HutCHINSON*
}

\begin{abstract}
Some years ago, I ran into a former colleague and ex-Dean. He was now a judge. After some friendly banter, he commented that he had recently read a piece that I had published about the hoary problem of 'state action' in constitutional law; it argued that the persisting doctrinal dilemmas were attributable to the contradictions of the underlying liberal basis of rights-talk. He had reason to read it, he said, because he had to decide a case that raised related problems about the institutional reach of Canada's Charter of Rights. However, after he had generously complimented me on the piece, he made a familiar complaint - 'For all the force of your critique, you never tell us what we should do. Don't you think that you should tip your hand and give us a sense of what we should decide?' I simply responded with my customary shrug and by saying that 'I'm not in the business of judging - that's your challenge, not mine'. His implicit sense of what academics do and should do was very different to my own.

In this short essay, I want to explain what is the 'business' that I think that I am in as an academic or, more grandly, as an intellectual. In particular, I will explore and explain what the implications of these intellectual commitments are for the fraught and misunderstood relationship between the academic and judicial (and, by implication, the professional) sectors of the legal community. In order to do this, I will first of all introduce an important distinction between the two different types of intellectual role - a traditional one and a critical one - that polarize law schools; this duality is far from original or unfamiliar. Then, I will take the recent confirmation process of Elena Kagan in her appointment to the United States Supreme Court to illustrate the political characteristics and institutional context which give rise to and sustain the pervasive acceptance by most law professors of their role as traditional intellectuals. Lastly, I will look at how this continuing nexus between judges and law professors affects academics in the way that they go about doing their intellectual business. Throughout the essay, I will emphasise that 'law is politics' and that there is no site of political innocence or independence that academics or judges can inhabit in meeting their professional roles and responsibilities.
\end{abstract}

\section{THE INTELLECTUAL BUSINESS}

While all law professors are intellectuals, they are not all intellectuals in the same way. Legal academics are squarely within the intellectual business of producing and trading in ideas and values about law, lawyers, and judging. That having been said, there is little more that can be stated by way of generalization about how they go about doing this, why they do what they do, and what interests they serve by doing it. While there is extensive and frequent debate within law schools about the role of judges and lawyers in society, there is no real continuing or regular debate about these more general intellectual roles and responsibilities of law professors. Indeed, law professors seem to go about their work as educators and scholars with little apparent anxiety about the particular intellectual and institutional context within which these roles are formulated and

\footnotetext{
Distinguished Research Professor, Osgoode Hall Law School, York University, Toronto. I am grateful to Ian Langlois, Derek Morgan, and ** for critical assistance and intellectual support.
} 
performed. Ironically, this stands in sharp contrast to the judicial community where there is considerable soul-searching, aided and encouraged by law professors, about what judges are supposed to be doing when they judge.

There are, of course, many different kinds of academics within law schools: they cover a broad spectrum of approaches, motivations, and interests. However, leaving aside those few who have become jaded and disengaged from any genuine work of a scholarly or even professional nature, serious law professors can be effectively divided into two main groups - the traditional and the critical. Although many law professors would resist this bifurcation as simplistic and there are a few who straddle the divide, the great bulk of legal academics can be easily categorized as 'traditional'. Some might claim that many legal academics have relinquished, if they ever upheld, the general designation as intellectuals at all. In Twining's familiar imagery, a large number of law professors are content to be thought of as talented plumbers, albeit with a touch of Periclean sophistication. ${ }^{1}$ Indeed, there are many legal academics who wear the badge of nonintellectualism and occasionally anti-intellectualism with a certain perverse pride.

Intellectuals are those who articulate and analyse the ideas, values, and commitments of the community, specialized or general, in which they live and function. For legal academics, therefore, the focus is on the intellectual constructs (eg legal doctrine, processes, institutions, personnel, etc) that constitute and energize the world of law and lawyers. While all legal academics do this work and gain their identity from it, they differ sharply over their approach to doing this. While traditional intellectuals are content to work within the established paradigms and to identify with its general interests and ambitions, the critical intellectual is less committed to the status quo and seeks to question the benefits gained and the interests served by those established values and ideas. ${ }^{2}$ Whereas traditional intellectuals see themselves as part of the same professional community as lawyers and judges, critical intellectuals align themselves with a broader and often different social context of allegiances. In short, traditional academics are members of the legal profession first and foremost: critical academics see their involvement with the legal community only as a necessary corollary to their more general identity as members of the professoriate.

The fact that most law professors operate and identify as traditional intellectuals does not mean that they commit themselves unreservedly or uncritically to the present values and ideas of the established order. Notwithstanding the few out-and-out careerists, they are not generally willing lackeys for the ruling elites or mindless dupes of a manipulative system. It is not the good faith of traditional intellectuals that is in issue. There are many legal academics that spend much of their time and effort criticizing legal decisions, lawyerly practices, doctrinal deficiencies, and the like. However, they do so in the name of enabling the overall legal process and personnel to fulfil better their customary purposes and expectations; they are there in an important sense as help-mates to lawyers and judges. Whether as critical doctrinalists or policy-wonks, they want to advance even as they alter the basic structures of law and its liberatory potential; their prestige and importance is tied to that of the legal process that they work to enhance. Problems with the legal process and its personnel are more about bad apples than the professional barrel itself.

On the other hand, critical intellectuals should not be portrayed as saintly and uncompromised figures that are entirely immune to the seductive blandishments and cooptive lure of traditional professional prestige; they strive to place some significant distance between themselves and the professional milieu, but they still remain within the

William Twining, 'Pericles and The Plumber' (1967) 83 Law Quarterly Review 396.

2 I am obviously drawing upon the general insights of Antonio Gramsci. See, Antonio Gramsci, Selection From the Prison Notebooks (1971). However, I want to offer some important modifications to Gramsci's typology in the legal academic context. Infra, pp.**. 
professional culture. Nor should critical intellectuals be seen as always against everything that the law claims to stands for; they are oppositionalists on behalf of some other set of commitments, not nihilists. Furthermore, critical intellectuals are not simply those who seek to represent the poor and oppressed under-classes. While this is an appealing prospect, it is unrealistic. The critical intellectual is opposed to established and vested interests which might well exclude a range of interests and ideas, some of which will not necessarily be consistent with or benefit the goals of the social under-classes.

It is tempting to assert that critical intellectuals speak 'truth to power'. However, this is a problematic notion. If that means that they should be 'a disturber of the status quo' and be prepared to challenge 'ideas and values despite the restrictions of a professional', ${ }^{3}$ all well and good. But, if speaking truth to power is meant to suggest that the critical intellectual must reside entirely outside the existing matrices of power, then this is too remote and detached a standard. ${ }^{4}$ There is no place of exile that the intellectual (or anyone else) can retire that is beyond the reach or influence of prevailing power structures and norms. There is no available 'outside' from which to engage in transformative action: all struggle for change is already sited and framed within the very mechanisms and mediums to be resisted and re-worked. While the university is often less infiltrated by those values than many other locations, it is not the fabled ivory tower of much popular imagination; the university is subject to a whole host of powerful forces, public and private, that combine to create a distinct discourse of values, ambitions and restrictions. This is especially so of law schools as this essay tries to make clear.

Accordingly, the critical intellectual must walk a thin line between being organically connected to and active on behalf of those people and interests which are outside the established order and being to the side of or on the margins of traditional institutions and contexts of power. ${ }^{5}$ This will be a shifting location as the currents and tides of the professional establishment ebb and flow. As such, the work of critical intellectuals is always vulnerable to being used by others to legitimize the very professional institutions and ideas that they oppose. Because they must live in law schools if they are to understand fully the professional culture's wiles and ways, they occupy a precarious ledge of existence; there are bound to be a few missteps and falls from critical grace.

This depiction of the intellectual life of law schools will be resisted by many. In my classification, they will see a too ready demonization of the traditional intellectual and a holier-than-thou romanticisation of the critical intellectual. There may well be some hints of that, but that is not my intention. However, I maintain that the basic thesis - most law professors are traditional intellectuals - is correct. A cursory glance at much contemporary scholarship, law school curricula, and pedagological methodology confirms that the commitment to a very strong and relatively uniform ethos of professional culture prevails. And this should come as no surprise. If one looks at the typical profile of the leading law professors and their institutional connection to bench and bar, it would be startling if this professional and traditional orientation was not the governing ethos of legal academe. Whether by way of cause or effect, the traffic between the bench and academe is most revealing of the mind-set of law professors as they go about their intellectual business.

\footnotetext{
Edward Said, Representations of the Intellectual (1994) x and 76. See, for example, Julien Benda, The Treason of the Intellectuals (1927).

For a further development of this idea, see, Allan Hutchinson, The Province of Jurisprudence Democratised (2009).
} 


\section{A CONFIRMING PRACTICE}

In May 2010, President Barack Obama nominated Elena Kagan for the vacancy on the Supreme Court of the United States on the retirement of the 89-year old Justice John Paul Stevens. After a relatively benign confirmation process, she was approved by a Senate majority of 63-37 and took up her appointment in August 2010. She was only the fourth woman to be appointed to the Supreme Court in its 219 year history. However, her background and career offer a neat encapsulation of the main theme of my essay - the close and mutually-sustaining relationship between the judicial and academic worlds and its effect on the intellectual climate of law schools. ${ }^{6}$

The daughter of a teacher and an attorney, Elena Kagan was an excellent student. After obtaining an undergraduate degree at Princeton and a postgraduate degree at Oxford in history, she received her JD (magna cum laude) from Harvard Law School in 1986; she was supervisory editor of the Harvard Law Review. From there, Kagan went on to be a law clerk for Judge Abner Mikva of the U.S. Court of Appeals for the District of Columbia Circuit in 1987 and then for Justice Thurgood Marshall of the U.S. Supreme Court in 1988. After a short period in private practice as an associate at the Washington, D.C., law firm of Williams \& Connolly, she joined the faculty of the University of Chicago Law School in 1991 and was promoted to a tenured professorship in 1995. Almost immediately, she left Chicago to serve as an Associate White House Counsel and later policy adviser under President Clinton. After a nomination to the United States Court of Appeals for the D.C. Circuit in 1999 (which expired without action), she took a visiting appointment at Harvard Law School where she was subsequently granted tenure in 2001. She became its first woman Dean in 2003. In early 2009, she was appointed by President Obama (himself a Harvard Law School graduate and former Chicago Law School professor) as the United States' Solicitor-General.

This is a stellar career by any standards. It is difficult for anyone to gainsay her achievements and talent. Although some commentators questioned her allegedly limited scholarly productivity, others noted that the quality of her work was very high and more than met any reasonable standards for academic or judicial competence. Throughout her life and work, she earned plaudits as a pragmatic consensus-builder who was balanced and constructive in her decisions and analysis. In both the corridors of power and the hallways of academe, she largely managed the not inconsiderable distinction of being able to gain the confidence and respect of both mainstreamers and more marginal figures. At the same time, she held firm to her own liberal convictions and was no fence-sitter. All in all, she blazed a trail that not only exceeded any reasonable expectations, but she did so without leaving a path of used and embittered individuals behind her. This is no mean feat in any field of contemporary endeavour.

Much of the confirmation process and public debate around her nomination was taken up with her lack of any judicial experience. She was not, of course, the first person without prior judicial experience. There had been about 40 of the 110 or so past Justices who joined the Supreme Court without holding any earlier judicial post; the last was William Rehnquist in 1972 and others include such luminaries as Earl Warren, Robert Jackson, Joseph Story, Louis Black and John Marshall. However, it is fair to state that this particular path to the Supreme Court is not as popular or accepted as it once was. Perhaps more revealingly for my purposes, Kagan is also not the first career-academic to find her way to the Supreme Court. The most well-known is Felix Frankfurter who went straight on to the Supreme Court from his tenured chair at Harvard; Kagan spent a short

6 Professional propriety requires me to state that I know Elena Kagan; she was Dean at Harvard when I was a visitor there. We remain on friendly terms. However, there is nothing in this essay that speaks to her personal character or professional integrity. I have every reason to think that she will be an exemplary justice. 
spell as Solicitor-General before her nomination. Also, present Justice Antonin Scalia went from Chicago Law School on to the U.S. Court of Appeals for the District of Columbia Circuit as did present Justice Ruth Bader Ginsburg who went the same route from Rutgers and Stanford. Many others have spent part of their career in the classroom and have added a scholarly publication to the resume.

It is the cyclical trajectory of Kagan's career that is most revealing. She did well in law school, clerked on the courts, went back to law school and, after periods of government work, and went back to the court. In this regard, she represents the archetypical model of the traditional academic and her route to judicial appointment is not uncommon among judges. Indeed, Justice Stevens whom she replaced had himself been a clerk to Justice Wiley Rutledge during the 1947-48 term and had been an adjunct professor at Chicago from 1953 to 1955 . Furthermore, Stevens himself had replaced Justice William Douglas on the Supreme Court who had also been a full-time professor at Columbia and Yale law schools. As well as Stevens, there have been four other Supreme Court Justices who previously clerked for other Supreme Court Justices: Justice Byron White clerked for Chief Justice Frederick M. Vinson, Justice Stephen Breyer clerked for Justice Arthur Goldberg, Chief Justice John Roberts, Jr. clerked for Chief Justice William H. Rehnquist, who himself had previously clerked for Justice Robert H. Jackson. Also, Breyer had been a Harvard law professor for over 25 years before his appointment to the Supreme Court.

Although many law professors do not get the chance to join the Supreme Court or other judicial bodies, many of the professors at elite American schools followed exactly the same path as Kagan from law school to a judicial clerkship and back to law school; it remains the most common and most reliable route to elite academic appointment. As such, Kagan's career path evidences the very tight and mutually-reinforcing dynamic between bench and academe. Her capacity and talent for moving almost seamlessly between and among the different sectors of the legal profession is especially remarkable. While her scholarly output (like that of other academic-judges, such as Breyer and Ginsburg) was far from uncritical of the courts and judges generally, the tenor of her writings fall squarely within the traditional genre of intellectual endeavour in that they are broadly devoted to chastising and correcting legal doctrines, processes, and personnel so that they better live up to and attain the professional ideals of law and judicial lawmaking. This, of course, is hardly surprising.

Of course, it does not mean that all who follow a similar path will end up at the same destination. The great majority of the law professors who were Supreme Court law clerks (and about $30 \%$ or so of those law clerks go on to be legal academics) ${ }^{7}$ do fall within and often openly align themselves with a more or less traditional intellectual orientation. Although there has been a greater extent of interdisciplinary research in recent years and a move away from purely doctrinal exegesis, the great bulk of contemporary scholarship remains devoted to advising courts how they might make a better job of their allotted institutional task. Nevertheless, there are a number of former law clerks that have taken the road less travelled; these are the exceptions that prove the general rule. For example, Duncan Kennedy a Harvard law professor, former law clerk to Justice Potter Stewart, and founder/leader of the Critical Legal Studies Movement, has largely rejected the traditional paradigm and has sought to develop a consistent practice of being a critical intellectual in his scholarship, teaching, and general professional activities. $^{8}$

7 See, William E. Nelson et al., 'The Liberal Tradition of the Supreme Court Clerkship: Its Rise, Fall, and Reincarnation?' (2009) 62 Vanderbilt Law Review 1749; Artemus Ward and David Weiden, Socerers' Aprrentices: 100 Years of Law Clerks at the United States Supreme Court (2006).

8 See, Duncan Kennedy, Legal Reasoning: Collected Essays of Duncan Kennedy (2008). 
This close, inter-dependent, and sustaining relationship between academics and judges is by no means unique to the United States. While it may be more marked and entrenched, other jurisdictions exhibit similar patterns and dynamics. In Canada, the most common path to the professoriate still remains a graduate degree combined with an appellate clerkship (which began in 1967). About $25-30 \%$ of academics followed this route and, if allowance is made for the number of non-Canadian members on Canadian law faculties, the percentage is even higher among Canadian-trained law professors. Since the late 1970s, the overwhelming majority of Canadian Supreme Court Justices have had at least a brief teaching career at law faculties. Indeed, some of the most renown Canadian justices have been drawn from the ranks of academe - Chief Justice Fateux was Dean at McGill before being appointed to the Superior Court of Quebec in 1947 and the Supreme Court of Canada in 1949; Chief Justice Laskin was a career academic and was appointed directly to the Ontario Court of Appeal in 1965 and to the Supreme Court in 1970; and Justice Beetz was Dean at the University of Montreal, before being appointed to the Quebec Court of Appeal and then to the Supreme Court in 1974. Also, several former clerks have now gone on to become judges themselves; Louise Arbour is a prime example of someone who was a law clerk at the Supreme Court, a career academic, and later a justice of the Supreme Court of Canada. If one looks to the provincial courts of appeal, the numbers of academics who have been appointed is relatively high. ${ }^{9}$

\section{INTELLECTUAL POLITICS}

It should be obvious from this broad accounting that the links between academics and judges are very close. However, this in itself says little about the nature of that relationship. In order to make my case, I need to show that there is a strong intellectual as well as institutional connection between academe and the judiciary. And, of course, I think that there is. Whether acting as plumbers or, more grandly, in a Periclean role, law professors tend to position themselves and produce work in support of the legal and especially judicial establishment; they create scholarship that strives to rationalise and legitimise the central importance and non-ideological performance of courts. Indeed, it is worth noting that Pericles himself was primarily a politician and military leader. Although he is lionized for his contributions to the artistic and literary world, he is viewed by many as tailoring those efforts to his overall imperialistic and civic ambitions. ${ }^{10}$ As such, insofar as he was an intellectual, he is very much of the traditional kind.

The major intellectual effect of this close allegiance between academics and judges is twofold - the primary focus of legal education and scholarship; and the approach taken towards it. First, while there are no doubt other important factors in play, the institutional interchange between judges and law professors has kept the details and doings of adjudicative decision-making at the very intellectual heart of the educational and scholarly agenda. Most classroom and scholarly debate centres on the work of judges in developing the common law, interpreting statutes and exercising constitutional review. Moreover, it is the work of appellate courts (where the clerkship

9 It is difficult to draw any general conclusions about Australia as clerkships are a relatively recent phenomenon. However, about 6 out of 48 (12.5\% or so) of the justices on the High Court were once academics, including former Chief Justice Anthony Mason, former Chief Justice Francis Brennan and present Justice Dyson Heydon. Many have held adjunct positions.

10 See, for example, Victor Ehrenberg, From Solon to Socrates: Greek History and Civilization During the $6^{\text {th }}$ and $5^{\text {th }}$ Centuries BC (1990). 
process is concentrated) that occupies the law students' energies and practicing lawyers' mentalities. All other legal activities are given secondary attention and, when considered, are studied in light of the judicial process. Of course, preoccupation with courts might be warranted in its own terms, but this unlikely. Today is a legislative and regulatory age; the great bulk of law-making and law-application is not done by courts, but by other agencies, officers, and citizens in less formal settings. Attention to such processes is still scant compared to that given to courts and litigation. As inculcated and nurtured by law professors, the primary knowledge and talent of lawyers is the capacity to slice-and-dice judicial pronouncements.

This court-centric focus is ample evidence of the intellectual consequence of the close academic-judicial nexus. However, it is the approach that most law professors and scholars bring to that subject-matter which is most revealing. To put it bluntly, traditional legal intellectuals recognize that their prestige and influence are closely tied to that of the courts. Therefore, there is a self-interested drive to show that the work of courts and, by implication, their own work is professional as opposed to political, independent as opposed to aligned, and balanced as opposed to partisan. Consequently, despite the occasional (judicial) lamentation that 'too few law professors are producing articles or treatises that have direct utility for judges',11 the major ambition of most traditional scholarship and teaching is to promote and defend the claim that judges can and should perform their responsibilities in a politically-neutral manner.

This does not mean that traditional academics approve of everything that judges do - far from it. However, as critical as they might be of particular judges and discrete judgments, they are defensive of the overall judicial project; the underlying thrust of their work is to defend the role of courts in constitutional democracies and to fashion accounts of how judges can do that in a manner that is both determinate, just and nonideological. Although there is massive disagreement among academics about how this best can be done, they are largely unified in their insistence that the ambition is both appropriate and realizable. The most obvious demonstration of this tendency is in the area of constitutional law where scholars proffer ever more imaginative and elaborate theories - textualist, originalist, republicanist, developmentalist, structuralist, moralist, popularist, etc - to explain how judges can and usually do fulfil their constitutional obligations in sufficiently objective and neutral ways. ${ }^{12}$ Other areas of law are no less rife, if less frenetically so, with similar efforts - utilitarian, Kantian, economic, evolutionary, etc - to ground the judicial process in some neutral and fixed footings.

Notwithstanding the merits and weaknesses of any particular theory or scholarly contribution, this entire intellectual project is as ideological as it can get. There is little more political in scope and effect than the traditionalist claim that 'law is not politics', but is somehow a mode of social activity and thinking that can lay claim to being both technically rigorous and substantively disinterested. Yet, it is hard to imagine other disciplines that claim a genuine intellectual legitimacy so closely connected to and part of the activities of those of whom they stand in judgment. It would be close to ridiculous to imagine literary scholars spending most of their time defending and acting as apologists for the publishing trade or political theorists devoting their energies to rationalising and shielding the machinations of the political establishment. Similarly, when law professors not only act as a group to bolster the extant and general performance of the judicial ranks, but do so as a matter of professional imperative, it is a conflict of intellectual interest on a massive and largely unacknowledged scale.

11 Harry Edwards, 'The Growing Disjunction Between Legal Education and the Legal Profession' (1992) 91 Michigan Law Review 34, 36.

12 For an excellent survey of the range and fecundity of this traditional project, see Thomas Baker, 'Constitutional Theory in a Nutshell' (2004) 13 William and Mary Bill of Rights Journal 57. 
Adjudication, especially at the highest appellate level, is not only a special social activity that causes or conditions other social activities and planning, but it also serves the important function of glossing its outcomes with an important veneer of naturalness and neutrality. As official bureaucracies, the judges help to persuade citizens that the courts are both a part of and apart from established political order and that their decisions, therefore, should be treated as less political than those of other government actors: '[it] is not so much that the court is the natural expression of popular justice, but rather that its historical function is to ensnare it, control it and to strangle it, by re-inscribing it within institutions which are typical of a state apparatus'. ${ }^{13}$ Consequently, participation in the legal process as lawyer or litigant, no matter how radical the claim or cause, runs the risk of reinforcing as it challenges the dominion of the status quo. As hackneyed as it sounds, law professors contribute to the vital political task of designing and stitching together those fashionable ideological outfits that outfit the judicial emperors who would otherwise appear even more institutionally-naked. None of this is to suggest a full-blown conspiracy between and among judges and law professors: it is simply the professional image that academics and judges adopt through a combination of self-interest, training, institutional allegiance, and habit.

In law schools, visiting judges are treated with a reverence that is more suitably reserved for visiting dignitaries or religious leaders; they are held in the highest regard and frequently placed on a ceremonial pedestal. It is simply taken for granted that, unless the judges themselves indicate otherwise, they will be treated with kid-gloves and spared any penetrating critique of their work; this is hardly conducive to a serious and unflinching intellectual inquiry. In terms of the intellectual fulcrum of legal scholarship, the overall flavour and sense of this academic-judicial imbalanced relationship is neatly captured by Mike Taggart:

... in the common law system it is the judge rather than the scholar that has had pride of place. The academic role has not been as glorious, central, or appreciated as the judicial one. ... Still, the barricades between the academy and the profession ... may not be completely gone today, but they are hardly visible. So a balanced approach to intellectual history would look at the thought and judgments of the more reflective and influential judges. For the most part those judgments have been the building blocks of scholars. ${ }^{14}$

This is quite the condemnation of the status and legitimacy of legal academics' work and standing. Under this depiction, the legal academic is not only engaged in a blatantly justificatory task, but is also very much the junior and less 'glorious' partner in this scholarly enterprise. While it is understandable that judges themselves might want to assure the public that their decisions are driven more by legal methodology than by their personal ideology, there are no reasons why academics should be such enthusiastic promoters of such a legitimating project. Indeed, as I have sought to explain, there are many reasons why it might behove legal academics not to do so. Ironically, it is that rogue-judge Richard Posner who puts it squarely when he concludes that 'the [academic] tendency [to defend the legitimacy of the judiciary] is paradoxically most pronounced at

13 Michel Foucault, 'The History of Sexuality' in Colin Gordon (ed), Power/Knowledge: Selected Interviews and Other Writing 1972-1977 (1980).

14 Michael Taggart, 'Prolegomenon to an Intellectual History of Administrative Law in the Twentieth Century: The Case of John Willis and Canadian Administrative Law' (2005) 43 Osgoode Hall Law Journal 223, 234 (footnotes omitted). 
the Supreme Court level, the paradox being that it is the most political court'. ${ }^{15}$ The Supreme Court is not only political in the effects that its decisions have, but also in the style, substance, and strategy of those decisions.

The transparency of this effort by most traditional academics is most obviously on display in and around the American confirmation process. Despite the paper-thin packaging and stylized posturing of various players, it is patently clear and almost universally accepted that modern-day Presidents select and nominate candidates who will hopefully uphold their own political values and thereby influence American politics long after the appointing President leaves office. For all her undoubted ability and intellectual competence, Elena Kagan was not selected in spite of her Democratic leanings, but because of them; she is expected by all sides of the political spectrum, for good and bad, to rely on her political commitments in fulfilling her judicial duties. It simply beggars belief that law professors can somehow maintain that, once Kagan writes and delivers judgments, she will somehow no longer be following her political convictions. Indeed, although there is no absolute match, the available studies are unanimous that ideological factors play an extensive role in judges' decisions and decision-making process. While judges may well drift over time in their ideological pre-dispositions (and, in the process, confound the partisan wishes of their appointing President), there is little doubt that these political commitments frame and direct the more legalistic arguments of judges.$^{16}$ It is not that judges ignore exclusively 'legal' arguments and methods, but that there are no such arguments and methods available that can be utilised or relied upon in a nonpolitical way.

\section{CONCLUSION}

No matter how much they try to deny or finesse it, judges and law professors are all in the politics business. And the greater vehemence with which they try to do so is only further evidence of their political complicity. The most pressing task is most definitely not to purge intellectual inquiry and debate of its politicalness - this is a self-defeating and impossible endeavour. What divides the traditional and critical intellectual is not whether they are engaged in a political enterprise, but whether they accept that they are, to which political interests they are prepared to harness their energies, and what they are prepared to do about it. This is not the end of genuine scholarship or intellectual inquiry as some contend; such doom-mongering is merely a further move in the traditional law professors' academic game. A recognition of the inescapable political dimensions of any intellectual pursuit is the first step in fulfilling its demands. Any alternative to the traditional legal project must look to engage, not escape, those social forces and political interests that combine to establish the prevailing economies of truth, power, and professionalism. Tackling those head-on is the best way of 'doing the business'.

My former colleague who was appointed to the courts likely deserved better than my off-hand remark that 'I'm not in the business of judging - that's your challenge, not mine'. I could have told him what to do in the facts of the case before him, but this would not have been a legal response, but a political one. While he was looking for some internal and coherent solution to his doctrinal and systemic dilemma, I would only be

15 Jonathan Masur, How Judges Think: A Conversation with Judge Richard Posner, $<$ http://www.law.uchicago.edu/alumni/magazine/spring08/posnerhowjudgesthink $>$ at $2^{\text {nd }}$ June 2010. Of course, I have offered extended arguments about what it means to say that 'law is politics'. See, Allan Hutchinson, It's All in the Game: A Non-Foundationalist Account of Law and Adjudication (2000).

16 See, for example, Lee Epstein, Andrew D. Martin, Kevin M. Quinn \& Jeffrey A. Segal, 'Ideological Drift among Supreme Court Justices: Who, When, and How Important?' (2007) 101 Northwestern University Law Review 1483 (2007). 
offering him my particular take on the problem in line with those political interests that I seek to advance. I suppose that amounts to 'business as usual'. 